\title{
The Silk Road between a Rock and a Hard Place: Russian and Chinese Competition for Central Asia's Energy
}

\author{
MORENA SKALAMERA*
}

aBstract China's displacement of Russian economic influence in Central Asia is generating great interest in Western academic and policy circles, but this research has, as yet, yielded few analytical nuances. This article attempts to shed light on the under-researched question of what explains Central Asian governments' failure to more effectively capitalize on the growing Central Asian rivalry between Russia, China, the United States, Turkey, Iran, South Korea, Japan, and other regional powers that, since the early 1990s, has been overwhelmingly directed towards strategic energy considerations and hydrocarbon interests.

\section{Introduction}

드 or centuries, from the first Tsarist-era conquests in the $18^{\text {th }}$ century and through 70 years of Soviet dominance in the $20^{\text {th }}$ century, Russia ruled the massive but thinly populated region of Central Asia. Central Asia is composed of arid steppes and mountains running from Siberia in the north, to the Pamir and Karakoram Mountains in the south and the Caspian Sea in the west. This massive area was generally known as Turkestan until the Soviet Union began to create smaller composite republics composed loosely along linguistic lines. Five republics were founded under the Soviet principle of economic collectivization, centralized political institutions and the Russian language as a lingua franca. Central Asia's abundant resources including oil, natural gas, minerals and cotton- went toward sustaining the Soviet economic machine, and road, railway, and pipeline networks linked the region to Russia. ${ }^{1}$

After the breakup of the Soviet Union, Central Asia's mineral riches and strategic proximity to Afghanistan and Iran prompted Russia, the former imperial overlord, to maintain close ties there. Energy exports from Central Asia were highly vulnerable to Russian pressure, with the Russian energy giant Gazprom con-
* Leiden University, Netherlands 2018, pp. 45-65 


\section{The Central Asian heads of}

states have failed to take full

advantage of their energy

wealth due to the reluctance

of local rulers to harmonize

their foreign policies and

present a united Central

Asian front when dealing with

external partners tory of heavy-handed threats to cut off supplies of oil and gas to its neighbors has made Beijing's job all the easier. China is at present the region's main source of foreign loans and the main market for its hydrocarbon exports. Gas pipelines are often arteries carrying geopolitical influence, and they increasingly head east to China.

\section{Power Transition and the Role of the Central Asian Republics}

The larger context of the change occurring in Central Asia is a power transition underway from Russia to China. Along the way, a great deal of literature has been devoted to addressing how the Central Asian states have adapted by playing the great powers off one another for their own benefit, and how, in this new "Great Game," the Central Asian states no longer play purely passive roles, but instead have become important players in their own right, especially in the energy sector. ${ }^{2}$ Central Asia expert, Alexander Cooley, observes that, in settings where several patrons or great powers vie for influence, the authority and influence of any one state are potentially diminished. ${ }^{3}$ Political scientist Annette Bohr concurs, noting that following Kazakhstan's lead, all of the Central Asian states have begun to adopt a 'multi-vector' foreign policy in order to gain maximum bargaining power with Russia, China, and the United States. ${ }^{4}$ This is especially true of the governments of oilrich Kazakhstan and gas-abundant Turkmenistan (where local leaders 


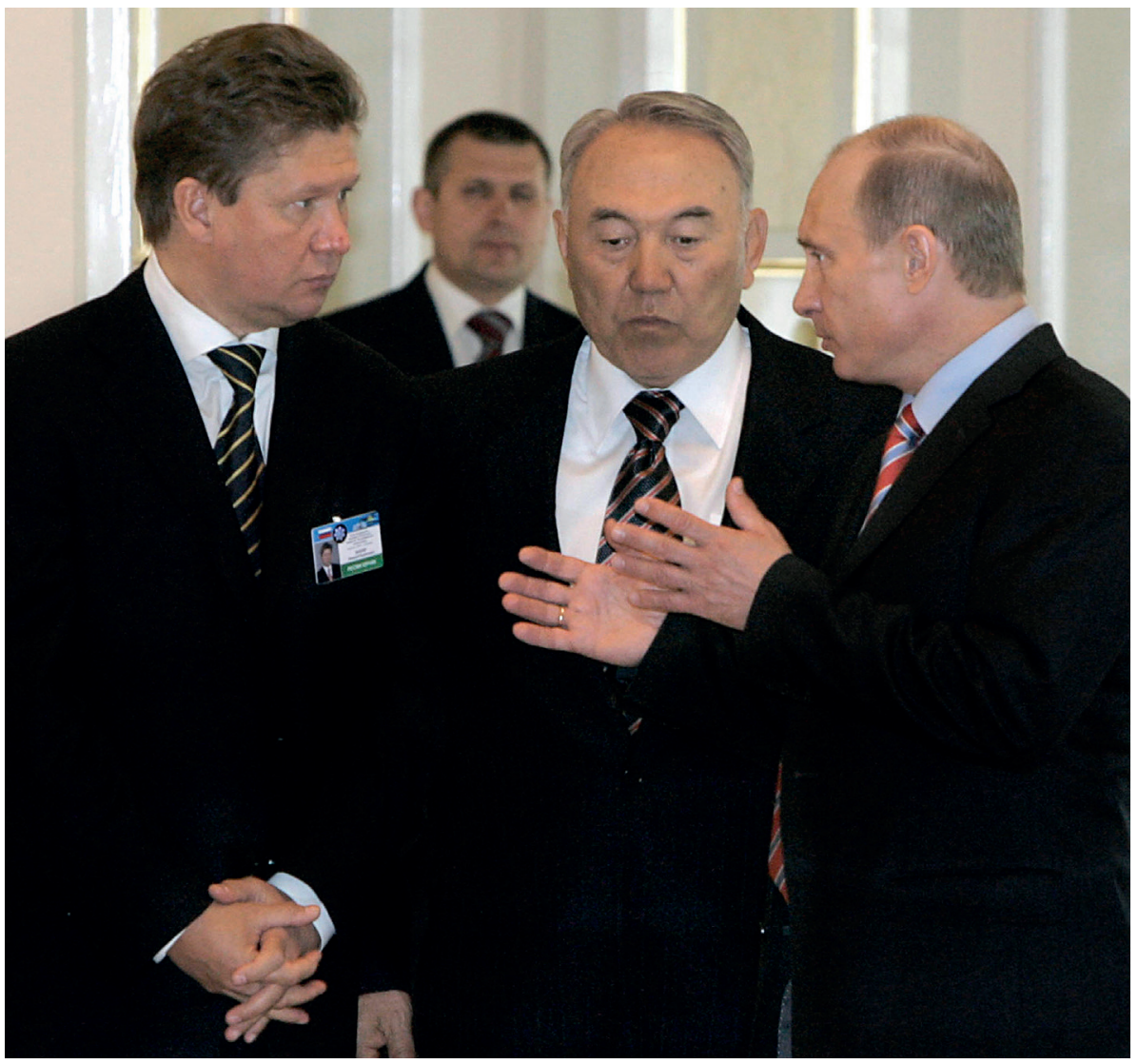

Russian and Kazakh presidents speak with the Russian Gazprom chief executive officer Alexei Miller during their meeting in Astana on May 10, 2007, where Nazarbayev vowed to boost energy ties with Russia.

had diversified away from the Soviet monopoly and exploitation of their resources), both of which appear to be pursuing a multi-vector strategy and emerging as independent players on the Eurasian energy map.

This paper takes issue with such an interpretation, however, contending instead that the Central Asian heads of states (with the partial exception of Kazakhstan) have failed to take full advantage of their energy wealth due to the reluctance of local rulers to harmonize their foreign policies and present a united Central Asian front when dealing with external partners, thereby failing to reap maximal benefits. In a similar vein, the evidence does not support the proposition that Central Asian elites have been able to directly play one external power off the other to extract increased assistance or better contractual terms over the years. Initially, China's growing involvement had the benefit of providing the necessary investment capital to begin to break the states' dependency on Russia. Reduced Russian influence did not, however, prompt the former Soviet states of Central Asia to formulate and consolidate their own independent energy strategies. Instead, both regional hegemons, 
China and Russia, have been able to apply the "divide and rule" tactic, with greater gains for themselves. Central Asia experts, Alexander Cooley and Marlene Laruelle, define this logic as 'supporting a client state and backing its claims in local disputes or conflicts in exchange for securing economic deals and political loyalty.'

The main argument presented here is that the current situation is due to the continued wavering of local leaders' foreign policies between Moscow and Beijing. This, in turn, stems from deficiencies in domestic politics, namely the inability of the Central Asian elites to show political vision beyond short-term tussles (the exception being Kazakhstan, which stands out for its strategic thinking) and to create an institutional environment that would enable the government to act in the long-term interest of the local people. Two factors, in particular, have been crucial in undermining Central Asian leaders' ability to project their economic interests internationally: their zero-sum minded politics and inability to work together to advance common interests in the face of largepower competition, and the influence of vested interests on policymaking.

It would be reasonable to expect that the reality of increased competition over the region's oil and gas riches would prompt local rulers to increase their efficiency, find ways to diversify their energy trade ties, and get more creative about their investment needs. But in highly opaque and tightly-controlled systems based on clientelism, Beijing's growing hold over Central Asia's energy infrastructure and markets through its \$1 trillion Belt and Road plan has meant that the benefits of such competition have been lost over time. If Chinese credit comes devoid of any political demands relating to governance and human rights, it also lacks interest in good governance, meaning that China does very little to engage with the local communities i.e. to ease tensions between Chinese workers and their host communities, preferring instead swift, top-down, government-to-government deals. ${ }^{6}$ Initially, Central Asian rulers welcomed China's involvement in the region, especially due to the economic benefits that China's colossal plan to build infrastructure across Eurasia offered. China avoided any discussions of domestic political affairs, which was also seen as positive. ${ }^{7}$

Growing Chinese economic investment, however, which operates under the sway of the Belt and Road Initiative, is currently viewed with a great deal of suspicion and resentment. Chinese companies, which profit handsomely from their energy deals in Central Asia, often employ Chinese workers for pipeline construction and energy extraction. These workers frequently clash with locals who resent being relegated to secondary positions. In 2009, China National Petroleum Corporation (CNPC) reportedly dismissed Turkmen workers who protested against wage arrears. ${ }^{8}$ The shift to China, moreover, has happened so fast that Central Asian leaders worry about China's long-term intentions and fear 
a possible Chinese migration. ${ }^{9}$ These concerns are most acute in Kazakhstan and Kyrgyzstan, where Chinese economic presence is the greatest and is expected to increase in the long term. In Kazakhstan, China’s plans to farm out one million hectares of arable but uncultivated land prompted large-scale protests. ${ }^{10}$

Even as ordinary Central Asians feel nervous about Chinese economic inroads, they are now left with fewer options, particularly after the United States and Western forces' withdrawal of combat troops from Afghanistan in 2014. Instead of having buttressed their economic position and political independence, most of the Central Asian countries were content with simply swapping their previous overwhelming dependence on Soviet-era pipelines and investment for a "Panda hug" from China.

More recently, several hawks in the Kremlin's military and political establishment have developed a vision of a "Great Russia" with strong ties to the former Soviet republics in Central Asia, reflecting Russia's increasingly status-driven posture in international politics. ${ }^{11}$ In resurgent Russia, greater preeminence is given to "clawing back value" in a region where, in Fyodor Lukyanov's words, "Russia doesn't want to be seen as China's junior partner." ${ }^{\prime 2}$

Some observers now claim that Central Asians are having second thoughts about their growing energy partnership with China and turning, once again, to their former imperial

\section{Even as ordinary Central}

Asians feel nervous about

Chinese economic inroads,

they are now left with fewer

options, particularly after the

United States and Western

forces' withdrawal of combat

troops from Afghanistan in

2014

master. ${ }^{13}$ For years, the local heads of state have pursued zero-sum policies vis-à-vis their other Central Asian neighbors with little room for compromise, failing to realize that their common interest lies in working together for the development of the region's hydrocarbon wealth rather than in switching allegiance from one great power to the other. As for China and Russia, it is not in their interest to encourage Central Asian states to come together as a whole. Certainly, both patrons have better reasons to stir up competition between them. According to simple market logic, the great powers improve their chances of getting better deals by pursuing "divide and rule."

\section{China's Energy Foray into Central Asia}

China's economic clout in Central Asia has caused a significant reduction of Russian economic influence in the region, and the loss of the sta- 


\section{The Central Asia-China gas}

pipeline, which runs through

China's restive $X$ injiang region,

marked a great success for

Central Asian leaders, since

it is the biggest export route

that reaches markets outside

Russia, bypassing its territory tus of the region's main energy trade partner. Yet it is important to note that Moscow views Central Asian natural gas as a backup source for external markets, whereas Beijing considers it a vital component of China's economic growth and prosperity.

In the early 1990s, Beijing's growing economic clout in the former Soviet periphery was gradually complemented by subtle military cooperation, mainly as a courtesy to Russia in exchange for stable Chinese-Russian strategic cooperation. ${ }^{14}$ As China's economic growth soared, however, the region became an attractive alternative for securing oil and gas overland, and thus insulated from potential U.S. sea-lane interdiction and free from the vagaries of Middle East politics. Central Asian gas was also cheaper (at least in the short to medium term), than buying LNG on the global market or developing domestic shale gas resources. It was from the early 2000s that the region became strongly tied to China through investment; Chinese energy firms were quick to grab the lion's share of assets in the region, particularly in gas-abundant Turkmenistan, which at the present is China's turf when it comes to natural gas.

The launching of two large oil and gas pipelines -the Kazakhstan-China oil pipeline, (the first section of which opened in 2003), and the Central Asia-China natural gas pipeline, (which began operating in 2009)cemented Beijing's energy foray into Central Asia. Over the years, both pipelines have significantly expanded. In 2017, the Kazakhstan-China oil pipeline transported 12.3 million tons of oil and $44 \mathrm{bcm}$ of natural gas, while the Central Asia-China natural gas pipeline sent $34 \mathrm{bcm}$ of natural gas in $2016 .^{15}$

Ostensibly, China has long wanted to develop its inland regions and push the industry to "go west" in order to spread its economic growth more evenly. Gas is now flowing through new pipelines and a web of roads and rails traversing the region -many built by China- and mimicking the earlier overland routes that had been the conduits for most trade between Europe, China, and India. ${ }^{16}$ In all this activity, it is China's use of energy diplomacy that has the most impact in the region. The Central AsiaChina gas pipeline (CAGP), which runs through China's restive Xinjiang region, marked a great success for Central Asian leaders, since it is the biggest export route that reaches markets outside Russia, bypassing its territory. The pipeline was built in 18 months, the fastest built pipeline of 
its size in history. The system is expected to reach full annual capacity (by more than doubling its offtake) to a massive $55 \mathrm{bcm} /$ year by $2019 .{ }^{17}$

China largely dominates Central Asian "upstream" energy development too. In 2013, CNPC acquired a stake in Kashagan, Kazakhstan's supergiant oil field development project. This was the second time that China prevailed over India in a contest for access to oil supplies from Kazakhstan (in 2005, CNPC, outbid the Indians for PetroKazakhstan). ${ }^{18}$ At present, Chinese companies own close to a quarter of Kazakhstan's oil production. ${ }^{19}$ These upstream oil investments, together with the opening of the gas pipeline network, sealed China's position as the region's number one energy partner.

As of 2016, Turkmenistan exports gas exclusively to China and Uzbekistan sells more gas to China than it sells to Russia. The quantity of Turkmen gas going to China is scheduled to go from 20 to $25 \mathrm{bcm}$ and to reach $65 \mathrm{bcm}$ by 2020 . This latter figure is roughly what Turkmenistan used to export to Russia and onwards via the Soviet-era Central Asia-Center gas pipeline system. In 2009, an explosion occurred at the Turkmenistan-Russia Central Asia-Center gas pipeline (by some accounts, caused by a rise in pressure resulting from Russia's failure to inform Turkmenistan that it had decreased its imports). Ever since, gas-pricing disputes between Ashgabat-based Turkmengas and Gazprom have vexed the Turkmen-Russian relationship.
As a result, Turkmen exports to Russia declined from more than $40 \mathrm{bcm}$ in 2008 to zero by 2017. Given that natural gas accounts for 80 percent of the government's revenue and 35 percent of the country's gross domestic product, Turkmenistan's economy now depends overwhelmingly on Beijing, in a classical patron-client relationship. ${ }^{20}$ There has been a lot of skepticism recently in the gas industry as to whether corruption-laden Turkmenistan will be able to meet its commitments to China subsequent to CNPC's decision to beef up the initial pipeline up $55 \mathrm{bcm}$. Just like in Iraq and neighboring Iran, China has struggled in Turkmenistan where estimates of gas reserves have been reduced due to the pervasive corruption and inefficiency that has plagued the projects since the initial surveys were completed.

Yet, Central Asia offers an ideal combination from China's perspective: greater energy independence from sea lanes dominated by the U.S. Navy, and enhanced leverage in bilateral negotiations with Moscow over its own energy resources (given the threat of alternative pipelines from Central Asia). China's turn westward is also driven by its desire to project influence into its hinterland, specifically in order to placate its restive Uyghur population in the Xinjiang province. While the east coast is industrialized and thrives, thanks to a booming manufacturing sector, the western interior remains largely poor and undeveloped. China's new Silk Road energy diplomacy reflects a 'look west' strategy to avoid third-country pipe- 
First, some have argued that China's economic rise in Central Asia took Russia by surprise and that commercial ties between Russia and the region have atrophied over the past decade. ${ }^{23}$ In this iteration of the argument, Russia's alleged neglect and overall economic weakness have caused its economic ties with the region to wither. The reality on the ground is more nuanced and profoundly complex. Russia has watched with unease as years of quiet diplomatic maneuvering have helped China step up its Central Asian presence by handing out billions of dollars in loans, snapping up energy assets and building an oil pipeline from Kazakhstan. But given China's growing economic might (Russia simply does not possess the kind of capital that Beijing has to develop mega-projects along the old Silk Road) and Russia's increasingly subservient role in its own relations with China (a partnership that for Moscow has become painfully necessary), there is very little the Kremlin could afford to do as China gradually displaced Russia as the largest source of trade and investment for most of the former Soviet republics of Central Asia. China is the biggest trading partner of four of the region's five countries (the exception being the region's largest economy Kazakhstan). The discrepancy is most striking in the case of Turkmenistan -where China accounts for 44 percent of the country's total trade while Russia makes up only 7 percent. ${ }^{24}$

Second, saying that trade relations between Russia and the Central Asia countries have atrophied is incorrect.

\section{Through SCO, China promotes}

its security ties in the region

in addition to forging bilateral

military cooperation with

the Central Asian republics.

Russia, nevertheless, remains

their principal security

provider and the main source

of arms

Russia still accounts for the largest share of Kazakhstan's trade and still supplies almost equal volumes of Uzbekistan's imports. However, China is right behind and is closing the remaining gap quickly. Russia remains a major economic force in Central Asia, and China's rise in the region complements its interests in many ways -or at least doesn't directly contradict them. The region is still linked to Russia through history and significant cultural and economic ties, for instance, remittances - a consequence of the outflow of labor migrants from Central Asia to Russiais still a strong source of economic influence for Moscow. ${ }^{25}$ Moreover, Russia does not need Central Asia's raw materials the way China does, and China does not need the region's low-wage labor force the way Russia does. The two countries' different economic structures are in many ways compatible.

This brings us to the third myth about Russia-China relations in Cen- 


\section{Europe's decline in demand simply translated into weakened Russian forays into Central Asian energy geopolitics}

even if it means turning a blind eye to Beijing's foray into Central Asia.

\section{Russia's Priority: Keeping Central Asian Gas in Asia}

Russia is no doubt concerned about China's growing presence in resource-rich Central Asia. China's deepening ties represent a geopolitical drawback that Moscow has attempted to mitigate (as the remaining principal military-strategic power in the region), thanks in part to the institutionalization of the Russia-sponsored CSTO (Collective Security Treaty Organization). China, instead, was instrumental in founding the Shanghai Cooperation Organization (SCO), of which Russia and four of the Central Asian nations are also members (Turkmenistan is the odd man out). Through SCO, China promotes its security ties in the region in addition to forging bilateral military cooperation with the Central Asian republics (for example, in counter-terrorism exercises). Russia, nevertheless, remains their principal security provider and the main source of arms.

Due to economic challenges, Russia has not invested much in the energy infrastructure of Central Asia since the end of the Soviet Union. Starting from 2008, an excruciating economic crisis hitting both Europe and Russia made Eurasian gas demand collapse, which meant that Russia no longer needed Central Asian gas to satisfy its own consumption or to send gas to Europe. Up to that point, Russia had sent the energy it imported from 
Central Asia to Europe to sell at a premium. Changing energy patterns in Europe (i.e. decreasing demand and, at the same time, new gas supply options in the wake of the U.S. shale boom) in the late 2000s created a substantial shift in Russia-Central Asia's energy ties. Gazprom, which historically had paid semi-barter prices for imports from Central Asia, announced that it had agreed to pay Kazakhstan, Uzbekistan, and Turkmenistan market prices for natural gas starting in 2009. The move was widely seen as Moscow's attempt to retain control of the market in the wake of China's aggressive moves to gain a stronger foothold. But eventually, Europe's decline in demand simply translated into weakened Russian forays into Central Asian energy geopolitics. ${ }^{26}$

This development explains why China's rise as Central Asia's energy hegemon does not necessarily conflict with Russia's strategic interests in the region. As Russia's energy supremacy declined, its efforts were overwhelmingly redirected to another crucial goal: preventing Central Asian hydrocarbons (in particular gas) from reaching European markets without Russia's intermediation. By the end of the decade, a resigned Moscow partly welcomed Turkmenistan's strides eastward as long as they hindered plans for the EU to gain access to Central Asian gas, therefore preventing unwelcome competition on the far more lucrative European gas market.

The EU (along with the support of the U.S.) has, since the breakup of the So- viet Union, pressed for multiple pipelines to move Central Asian gas to European markets. It has, in particular, backed two pipeline projects, namely the Nabucco and the Trans-Caspian pipeline, both of which sought to circumvent Russia by transporting gas from the Caspian region to Europe via Turkey and the Balkans. Yet with the inauguration of the massive Central Asia-China gas pipeline to the east, it became questionable whether and when Turkmenistan would have more gas to feed into another gas pipeline directed to the EU. This is why the recent hype surrounding the resolution of the decades-long dispute over the Caspian Sea is probably overblown. Under the newly reached formula for dividing up the Caspian, all five littoral states still have a say on environmental protections. ${ }^{27}$ It is well documented that Russia objects (ostensibly on grounds of environmental sustainability), to energy projects that hurt its national interests. A few notable examples include the vetoing of the Transneft pipeline to Nakhodka around Lake Baikal and Yukos' project to Daqing on environmental grounds, although Gazprom has built similar or even more technically hazardous projects in the Black and Baltic Seas. ${ }^{28}$

In short, Russia has been forced into a "junior" position in the energy sphere in its ex-imperial backyard. But this does not mean that Russia's interests have been fully displaced. When it comes to preventing another, potentially much more unnerving energy development, (i.e. making sure that no Central Asian gas would compete 


\section{As China's profile in Central}

Asia continues to rise, Russia's

inclination is to influence

the region's affairs through

fait accompli and trump

cards, which still give Russia preeminent influence with its own in Europe), Russia's Central Asian strategy has been largely successful. Despite the significant EU-wide desire to "diversify" gas imports, the only Caspian gas pipeline that "escaped Russia" thus far is a much smaller than planned (10 bcm pipeline) from Azerbaijan, which falls far short of reaching real diversification away from Russian gas.

\section{Russia Takes a Page from China's Soft Power Playbook}

Meanwhile, Russia's recent increased meddling in Central Asia is strongly related to Moscow's strategic efforts to project power in its own hinterlands and to safeguard its vital interest in what is considered its immediate 'sphere of influence.' In that respect, as China's profile in Central Asia continues to rise, Russia's inclination is to influence the region's affairs through fait accompli and trump cards, which still give Russia preeminent influence.

Taking into consideration the complex political, cultural, and ethnic realities stemming from the Soviet
Union's demise, Russia still retains several important advantages over China in the region. These include traditional administrative and personal ties between the Russian and Central Asian political and economic elites dating back to the USSR. In all five countries, Russian remains the international lingua franca. Most people watch Russian-language television channels, through which Russia successfully wields "soft power" and its own propaganda. ${ }^{29}$

While both Russia and China are engaged in an ongoing "great game" for the hearts and minds of the five former Soviet republics, in the case of China, it is mostly their energy wealth and mineral resources that motivate such outreach. ${ }^{30}$ Beijing is making serious inroads there, not least because of its deep pockets, but China's "Belt and Road Initiative" is devoid of an appealing ideology that would capture the hearts and minds of the local population. For instance, when in 2016 the Kazakh government, hoping to raise productivity, passed a law that would allow foreigners to rent farmland for up to 25 years, mass protests ensued. The fear that Chinese multitudes would occupy empty Kazakh land and never leave was palpable. The government was forced to put the plan on hold. ${ }^{31}$

Russia also dominates regional security, another source of "soft power" in countries that have great respect for displays of raw military might. Moscow, moreover, has claimed the right to intervene wherever ethnic Russians are in trouble; one-fifth of Kazakh- 
stan's population is Russian. Instability caused by a developing Islamic revival in the region, or potential ethnic unrest within the nations with strong Russian minorities could potentially have negative consequences for Russia itself, explaining why Russia remains vigilant in the region.

Russia is still a role model in the fields of mass communication, popular culture, education and science. It remains the critical arbiter and balancer in the competition among the five Central Asian nations, and significant advantages will still accrue to any future Russian partner due to the dependence of some Central Asian countries on Moscow-controlled water and electricity supplies. ${ }^{32}$ One such (eye-catching) example is the reliance of the hydrocarbon-rich Atyrau and Mangystau provinces of western Kazakhstan on Russian electricity and water supplies, which are crucial for the successful operation of the local hydrocarbon-producing infrastructure..$^{33}$ Despite the relative decline in Russian economic and corporate involvement across the overall Central Asian energy sector, the Kremlin uses its strategic advantages over selected external actors, and it still retains great influence over Kazakhstan, Kyrgyzstan, and Tajikistan, as they are all members of Russia-backed security and economic mechanisms, such as the Eurasian Economic Union. ${ }^{34}$

It was recently reported that the leaders of Russia, Iran, Kazakhstan, Azerbaijan, and Turkmenistan signed the Convention on the Legal Status of the Caspian Sea, settling a decades-long dispute. Turkmen authorities now hope to get the so-called Trans-Caspian Pipeline built, which would bypass Russia. Two important problems remain: first, the inability of Turkmenistan to commit to substantial sources of gas in the West given its current commitments in the East, and its enduring reluctance to allow international companies to secure anything more than service contracts onshore. ${ }^{35}$ Second, despite recent diplomatic pleasantries, Russia's strong opposition to east-west energy trade through Caspian subsea pipelines.

Most crucially, Russia will continue to strongly oppose any Central Asian hydrocarbon exports that bypass Russian territory and that have the potential to undermine Russia's energy business in Europe. In view of this, Russia is likely to cooperate with China, India, Pakistan, and Afghanistan in Central Asia so as to engage regionally-produced hydrocarbons elsewhere rather than in Europe. ${ }^{36}$

\section{Beijing Defers on Moscow's "Energy Club"}

As Chinese companies moved to enhance their positions in Central Asia, the Kremlin became keen to establish an energy club as a means to prevent a possible clash with China over the region's energy resources. In 2008, Moscow advanced the idea of forming such an energy club within the SCO to "harmonize the energy strategies of Russia, China, and Central Asian countries." 37 To some extent, Beijing has been careful to coordinate 
with Moscow on the economic initiatives it pursues in Central Asia, and has adopted a largely collaborative approach. At the same time, China has remained non-committal on the energy club idea. ${ }^{38}$

China's reluctance demonstrates that despite the public fanfare and the abundance of symbolism in the China-Russia bilateral relationship (i.e. China frequently "defers" to Russia, and offers assurances to manage Russian concerns over the imbalance in relations), increasingly, Chinese energy engagement in Central Asia is likely to take place on its own terms. China is an energy consumer, whereas Russia and the SCO Central Asian members, Uzbekistan and Kazakhstan are energy producers, so Beijing has no interest in engaging in any multilateral dialogue with the SCO as an umbrella.

On the other hand, the growing interest of the two giants in Central Asian energy supplies should have, ideally, prompted Central Asian leaders to come up with some sort of multilateral forum for facilitating energy dialogue among themselves and presenting a united front on energy deals. Though the five countries share a common history, their post-Soviet paths have diverged, and they are often at loggerheads with each other.

The Central Asian countries have yet to learn how to work together to advance common interests in the face of large-power competition, and there is little prospect of this changing in the near future.

\section{Central Asian Bluster Backfires}

It is currently unclear whether the Central Asian countries could forge closer cooperation for facilitating energy dialogue. Turkmenistan remains a mercurial and isolated country. Like Turkmenistan, Uzbekistan is closed and inward-looking, although the recent leadership change offers some hope for the future. Uzbekistan could be a game changer, but it remains to be seen whether the recent change under the watch of Shavkat Mirziyoyev will truly enable Uzbekistan's "Spring" or if the country will remain isolated. ${ }^{39}$ Kyrgyzstan and Tajikistan are largely reactive to other actors in the region. Moreover, Kyrgyzstan and Tajikistan are Moscow's classic client states, while Turkmenistan is 
now completely in the Chinese fold. The only country that has managed to develop a somewhat independent foreign policy is Kazakhstan, with its strong bilateral ties with Russia and China, as well as the United States. The region is far from monolithic and the diversity of energy agendas and the economic standings of the Central Asian countries has, thus far, made energy cooperation under any kind of multilateral umbrella highly problematic. Central Asian domestic institutional structures, which are personalist and opaque, are viewed as central to shaping secretive state-tostate economic deals where the room for rent-seeking is the largest.

Since the breakup of the Soviet Union, Central Asian leaders have been ridden by internal rivalries and rows over the cross-border use of natural resources. These internal divisions, a preference for concluding agreements bilaterally and in secret, hypersensitivity to efforts by outside powers to intervene in internal affairs and, accordingly, unwillingness to cede decision making power to any supranational body, partly explain why the Central Asian autocrats assemble so rarely to discuss regional energy cooperation. ${ }^{40}$ In their dealings with the former imperial master, Russia, Central Asian countries had often willingly accepted Moscow's behind-the-scenes political meddling in exchange for fat bilateral deals for well-placed local insiders. ${ }^{41}$ Over the past three years, the relative decline in their energy ties with Russia has cemented energy policy as the mainstay of Chinese influence in Central Asia.

\section{The formation of the $\mathrm{C} 5+1$}

coalition, which brings the United States and the five Central Asian countries together, is a good start for

a region whose individual disparities have thus far precluded collective engagement

Yet China's success in making the Central Asian states' goal of market diversification a reality did not bring tangible benefits to the Central Asian people as a whole. With China too, Central Asian strongmen show a preference for bilateral agreements (on large energy infrastructure and the Belt and Road projects), thereby avoiding any involvement from Moscow, despite Russia's insistence that such agreements be done through the Eurasian Economic Union (EEU) framework. ${ }^{42}$ China's own corruption scandals and recent "purges" mean that China has not refrained from efforts to cooperate quietly, through bilateral channels; as Paul Stronski and Nicole Ng note, this also suggests it sees limited value in the SCO. ${ }^{43}$ Energy expert Aminjonov argues that due to their persistent quest for rents, corrupt Central Asian elites simply swapped complete dependence on Moscow to transport oil and gas from Central Asia to international markets with almost total reliance on a sin- 
gle Chinese gas market. ${ }^{44}$ As noted earlier, the persistent unwillingness among Central Asian countries to engage in compromise to ameliorate their bargaining position vis-à-vis external partners has led the Central Asian governments toward increasing stagnation and lose-lose scenarios.

\section{The Water Issue: Nearing a Boil?}

One issue still slowing down the growth of mutual trust among the Central Asian republics' relations is the water problem. 80 percent of Central Asian water resources originate in Kyrgyzstan and Tajikistan but are mostly consumed by Uzbekistan, Kazakhstan and Turkmenistan. When they were still a part of the Soviet Union, the upstream republics -Kyrgyzstan and Tajikistan- which have an abundance of water, would release some from their reservoirs in the spring and summer to generate electricity and nourish crops both on their own land and in the downstream republics, which would return the favor by providing gas and coal each winter. But since the dissolution of the Soviet Union over a quarter century ago, that system has collapsed. ${ }^{45}$ The controversy is that Kyrgyzstan and Tajikistan want to discharge water for power generation mainly during the winter, while the downstream countries need water for irrigation in the summer. ${ }^{46}$ For a long time after the collapse of the USSR, Russia stayed somewhat neutral on the disputed issue; more recently Moscow has tried to defuse the conflict by taking the stance of a mediator. ${ }^{47}$ The water problem has now become a considerable factor in shaping Moscow's relations with Central Asian countries. Moscow has proposed compromise solutions; for instance, to facilitate the involvement of Uzbekistan and Kazakhstan in the construction of new hydropower facilities in Kyrgyzstan. ${ }^{48}$ In July 2014, Gazprom took over Kyrgyzstan's gas network with the promise of ensuring that Bishkek has a stable and affordable supply. Many Kyrgyz citizens criticized the sale of KyrgyzGaz to a gas company owned by their former imperial master. The deal came as Russia was promoting an economic and political alliance, the Eurasian Economic Union, which Kyrgyzstan joined the following year despite questionable benefits. ${ }^{49}$

Probably the most serious Russian leverage over Kyrgyzstan is now energy transmission; Moscow agreed to make substantial financial concessions to Bishkek as regards the writeoff of the debt and assistance in the construction of the Kambarata-1 hydropower station, but Kyrgyzstan lost its autonomy in decision making on international energy trade issues. ${ }^{50}$ Moscow hardly gained any financial advantage from the transaction but the move does enhance its role as a regional mediator at the expense of China. This trend could also transform Gazprom's role in the regional transportation of gas, as Gazprom now positions itself as an intermediary, able to help bring about improvement in Kyrgyzstan's relations with Uzbekistan. One cannot rule out that it is exactly in the context of 
binding Kyrgyzstan to Russia and redeeming it from growing Chinese influence that in April 2014, Gazprom took over the country's gas network, pledging "a stable gas supply." ${ }_{11}$ The takeover has close to zero economic advantages for Gazprom, which inherited the Kyrgyz national energy operator's debt toward neighboring Uzbekistan, but it may have numerous other advantages as a powerful tool of traditional, Kremlin-led statecraft in Central Asia.

Meanwhile, among the Central Asian countries themselves, regional problems related to the plans of Kyrgyzstan and Tajikistan to build giant dams to provide for their energy needs have turned into serious antagonism. For instance, the dispute between Dushanbe and Tashkent provoked a transportation blockade imposed by Uzbekistan because of its disagreement with the Rogun hydropower station construction project. More recently, Tajikistan's Rakhmon and the new President of Uzbekistan, Mirziyoyev, diffused the conflict and electricity trade resumed. Tajikistan has now completed the first stage of Rogun and plans to start producing electricity in 2019.

Despite such encouraging signs, over the years the Central Asian republics have become increasingly divisive and distrusting of one another, as reflected in the back-and-forth border closures between Turkmenistan and Kazakhstan and recently, Kazakhstan and Kyrgyzstan. ${ }^{52}$ This dynamic in the region complicates relations inside the SCO, which is comprised of

\section{With the West's withdrawal}

from Afghanistan and the U.S.' recent "America First" mantra, the window of opportunity for the Central Asian

governments to ameliorate their energy security positions through diversification is slipping away

China, Russia, and all the countries of the region except Turkmenistan. Due to simmering regional rivalries, mega-projects like Nabucco have been shelved. Azerbaijan, for instance, quietly welcomed a dispute over the status of the Caspian Sea for as long as it prevented Turkmen gas from being able to compete with its own on the EU market. ${ }^{53}$ On the positive side, the formation of the $\mathrm{C} 5+1$ coalition, which brings the United States and the five Central Asian countries together, is a good start for a region whose individual disparities have thus far precluded collective engagement. ${ }^{54}$

\section{Conclusion}

Current evidence does not support the received wisdom that competition over Central Asian resources is a "great game" that the Central Asian gas suppliers -Turkmenistan, Kazakhstan, and Uzbekistan- have become increasingly adept at playing to their advantage. Rather, instead of 


\section{As China becomes the}

region's new energy

hegemon, it increasingly

appears that Central Asian

leaders have fallen into an old

trap and have simply traded

one imperial master for

another security positions through diversification is slipping away. Rent-seeking, motivated Central Asian elites find it especially convenient to deal with Chinese partners, given that Beijing offers generous trade and loan terms, while at the same time taking a handsoff approach to domestic political affairs. Unlike Washington, Beijing doesn't press the autocratic Central Asian leaders to agree to a timetable and agenda for internal reforms.

Hence, what the Central Asian heads of states have often termed as a "multi-vector" equilibrium policy in practice points only to the region's two largest neighbors; large energy companies from Russia and, overwhelmingly, China, have been allowed to exploit Central Asian resources in exchange for improved relations. Conventional wisdom, indeed, has it that being located atop some of the world's biggest oil, gas and metals reserves, Central Asia is at the center of a geopolitical tug-of-war between Russia and China, with both seeking to grab a dominant share of its untapped riches. This paper, however, has argued that even as Russian and Chinese energy companies wage a spirited competition over Central Asian resources, the region simply is not the primary apple of discord in the two giants' bilateral partnership. Instead, it is Central Asian countries themselves that lose the most from their inability or unwillingness to work in unison. Mismatch among Central Asian countries' individual approaches to "energy security" and their lack of coordination signals problems ahead. 
Having been released from the controlling grip of the Soviet Union only slightly less than three decades ago, the Central Asian countries are not eager to be dependent on anyone. But with their lack of vision and reluctance to work together, this is exactly the scenario they might end up with. Although China's approach as an energy hegemon in Central Asia is different from Russia's post-Soviet quest for continued influence, China will not shy away from aggressive buttressing of its economic position, and there have been growing concerns that China is using the SCO, an eight-member bloc designed to coordinate security policies across Asia, as a vehicle to promote its Belt and Road Initiative. ${ }^{56}$

As China becomes the region's new energy hegemon, it increasingly appears that Central Asian leaders have fallen into an old trap and have simply traded one imperial master for another. Unless the Central Asian states learn that it pays to put aside their rivalries and present a united front on energy deals, a region that accounts for around 3.5 percent of the world's proven oil reserves and around 6.8 percent of world's gas reserves will have trouble reaping the benefits offered by the great powers' contest for their natural resources wealth.

\section{Endnotes}

1. "Assessment: Central Asia's Economic Evolution from Russia to China," Stratfor Worldview, (April 5, 2018), retrieved from https://worldview.stratfor. com/article/central-asia-china-russia-trade-kyrgyzstan-kazakhstan-turkmenistan-tajikistan-uzbekistan.
2. Alexandros Petersen and Katinka Barysch,"Russia, China and the Geopolitics of Energy in Central Asia Report," Centre for European Reform, (November 2011), retrieved from https://www.cer. eu/publications/archive/report/2011/russia-china-and-geopolitics-energy-central-asia, p. 4.

3. Alexander Cooley, Great Games, Local Rules: The New Power Contest in Central Asia, (Oxford: Oxford University Press, 2012), p. 9.

4. Annette Bohr, "Central Asia: Responding to the Multi-Vectoring Game," in Robin Niblett (ed.), America and a Changed World: A Question of Leadership, (Hoboken: Wiley-Blackwell, 2010), p. 110.

5. Alexander Cooley and Marlene Laruelle, "The Changing Logic of Russian Strategy in Central Asia: From Privileged Sphere to Divide and Rule?" PONARS Eurasia Policy Memo, No. 261 (July 2013), retrieved from http://www.ponarseurasia.org/ memo/changing-logic-russian-strategy-centralasia-privileged-sphere-divide-and-rule.

6. The author interviewed Uzbek policy expert and former government official, Almaty on February 2017 . On the same topic, the author interviewed a political expert from Kazakhstan on November 2017.

7. See, for instance, Martha Brill Olcott, "China's Unmatched Influence in Central Asia," Carnegie Endowment for International Peace, (September 18, 2013), retrieved from https://carnegieendowment.org/2013/09/18/china-s-unmatched-influence-in-central-asia-pub-53035.

8. Paul Stronski, "Turkmenistan at Twenty-Five: The High Price of Authoritarianism," Carnegie Endowment for International Peace, (January 30, 2017), retrieved from https://carnegieendowment.org/2017/01/30/turkmenistan-at-twentyfive-high-price-of-authoritarianism-pub-67839.

9. Sebastien Peyrouse, "Discussing China: Sinophilia and Sinophobia in Central Asia," Journal of Eurasian Studies, Vol. 7, No. 1 (2016), pp. 14-23. See also, "China in Central Asia: Rising China, Sinking Russia," The Economist, (September 14, 2013), retrieved from https://www.economist.com/asia/ 2013/09/14/rising-china-sinking-russia.

10. Dosym Satpaev, "Kitaiskaya Ekspansiya: Mify i Realii [Chinese Expansion: Myths and Reality]," Forbes Kazakhstan, (January 17, 2013), retrieved from https://forbes.kz/process/expertise/kitayskaya_ekspansiya_mifyi_i_realii/. On concerns related to China's OBOR, see also, Nargis Kassenova, "Information on the Projects Should Be Available to the Public," Friedrich Ebert Foundation Comment, (February 26, 2018), retrieved from https:// www.fes-connect.org/people/information-on- 
the-projects-should-be-available-to-the-public/.

11. Russia's Siloviki, many of whom are close associates of President Putin (e.g. Igor Sechin and Sergei Shoigu) have long advocated closer ties to China and a forward posture in Russia's near abroad. For a compelling analysis, see, Brian D. Taylor, "The Russian Siloviki and Political Change," Daedalus, Vol. 146, (Spring 2017), pp. 53-63.

12. Brian Whitmore, "Central Asia: Behind the Hype, Russia and China Vie for Region's Energy Resources," RFE/RL, (March 22, 2008), retrieved from https://www.rferl.org/a/1079674.html.

13. Morena Skalamera, "Russia's Lasting Influence in Central Asia," Survival, Vol. 59, No. 6 (2017), pp. 123-142.

14. "China's Long March into Central Asia," Stratfor Worldview, (April 27, 2016), retrieved from https:// worldview.stratfor.com/article/chinas-longmarch-central-asia.

15. "Central Asia's Economic Evolution from Russia to China."

16. The Old Silk Road was a network of interlinking corridors that formed a spider web of connections across Eurasia. See, "New Rail Routes between China and Europe Will Change Trade Patterns," The Economist, (September 16, 2017), retrieved from https://www.economist.com/ business/2017/09/16/new-rail-routes-betweenchina-and-europe-will-change-trade-patterns.

17. Michael Lelyveld, "China Nears Limit on Central Asian Gas," Radio Free Asia, (June 25, 2018), retrieved from https://www.rfa.org/english/commentaries/energy_watch/china-nears-limit-oncentral-asian-gas-06252018100827.html.

18. Vladimir Socor, "China Enters Kashagan Oil Project, Will Boost Kazakhstan-China Pipeline Capacity," Eurasia Daily Monitor, Vol. 10, No. 125 (July 9, 2013).

19. "National Energy Report 2015," Kazenergy, (2015), retrieved from http://www.kazenergy. com/upload/document/energy-report/NationalReport15_English.pdf, p. 113.

20. "Central Asia's Economic Evolution from Russia to China."

21. For an in-depth analysis of China's 'Continentalism' see, Kent Calder, The New Continentalism: Energy and Twenty-First-Century Eurasian Geopolitics, (New Haven: Yale University Press, 2012).

22. Joshua Walker and Kevin Kearney, "What Central Asia Means to the United States," The Diplomat, (September 16, 2016), retrieved from https://thediplomat.com/2016/09/what-centralasia-means-to-the-united-states/.
23. Paul Stronski and Nicole Ng, "Cooperation and Competition: Russia and China in Central Asia, the Russian Far East, and the Arctic," Carnegie Endowment for International Peace, (February 18, 2018), retrieved from https://carnegieendowment.org/ 2018/02/28/cooperation-and-competition-russia-and-china-in-central-asia-russian-far-eastand-arctic-pub-75673, p.14.

24. "Central Asia's Economic Evolution from Russia to China."

25. For a detailed discussion, see, "Central Asia's Silk Road Rivalries," International Crisis Group, No. 245 (July 27, 2017), retrieved from https://www. crisisgroup.org/europe-central-asia/central-asia/ 245-central-asias-silk-road-rivalries.

26. Morena Skalamera, "Revisiting the Nabucco Debacle," Problems of Post-Communism, Vol. 65, No. 1 (2018), pp. 18-36.

27. Andrew E. Kramer, "Russia and Four Other Nations Settle Decades-long Dispute over Caspian Sea," The New York Times, (August 12, 2018), retrieved from https://www.nytimes.com/2018/08/ 12/world/europe/caspian-sea-russia-iran.html.

28. For a compelling discussion of these dynamics see, Thane Gustafson, Wheel of Fortune, (Cambridge: Harvard University Press, 2012). Circumstantial evidence also has it that Russia has funded anti-fracking groups in Europe. Fiona Harvey, "Russia 'Secretly Working with Environmentalists to Oppose Fracking,"' The Guardian, (June 19, 2014), retrieved from https://www.theguardian.com/environment/2014/jun/19/russia-secretly-working-with-environmentalists-to-oppose-fracking.

29. "Stans Undelivered," The Economist, (June 30, 2016), retrieved from https://www.economist. com/asia/2016/06/30/stans-undelivered

30. Kazakhstan, Turkmenistan and Uzbekistan are attractive for their energy wealth. Tajikistan and Kyrgyzstan are rich in minerals.

31. "Kazakhstan: The Crossroads of the New Silk Road," The Economist, (July 1, 2017), retrieved from https://www.economist.com/asia/2017/07/01/ kazakhstan-the-crossroads-of-the-new-silk-road.

32. The author interviewed with Kazakh government representative, Astana, November 2016; author interviewed with Uzbek governmental adviser, Almaty, February 2017; and author interviewed with Western diplomat, Bishkek, October 2016.

33. The entire power infrastructure in Kazakhstan's western region is connected to Russian grids. For a wider discussion see, "Russia's Interests 
in Central Asia: Contents, Perspectives, Limitations Report," RIAC, No. 10 (2013), retrieved from http://russiancouncil.ru/upload/RIAC_Central_ Asia_En.pdf.

34. Shamil Midkhatovich Yenikeyeff, "Energy Interests of the 'Great Powers' in Central Asia: Cooperation or Conflict?" The International Spectator, Vol. 46, No. 3 (2011), pp. 61-78.

35. See, for instance, John Roberts, "Will Central Asia's Oil and Gas Go East or West?" BBC News, (June 1, 2010), retrieved from https://www.bbc. com/news/10185429.

36. Yenikeyeff, "Energy Interests of the 'Great Powers' in Central Asia: Cooperation or Conflict?"

37. "SCO Member States Agreed to Establish Energy Club," Kazenergy, (December 9, 2013), retrieved from http://kazenergy.com/ru/prss/2011-04-2110-41-35/12013-2013-12-09-04-09-08.html.

38. Sergei Blagov, "Russia Urges Formation of Central Asian Energy Club," Eurasianet, (November 6 , 2007), retrieved from https://eurasianet.org/ russia-urges-formation-of-central-asian-energyclub.

39. For an interesting explication of the "Spring" logic, see, Edward Schatz, "How Western Disengagement Enabled Uzbekistan's "Spring," and How to Keep It Going," PONARS Eurasia Policy Memo, No. 531 (June 2018), retrieved from http:// www.ponarseurasia.org/memo/how-westerndisengagement-enabled-uzbekistans-springand-how-keep-it-going.

40. Kathleen Collins, "Economic and Security Regionalism among Patrimonial Authoritarian Regimes: The Case of Central Asia," Europe-Asia Studies, Vol. 61, No. 2 (2009), pp. 249-281. See also, Erika Weinthal and Pauline Jones Luong, "Combating the Resource Curse: An Alternative Solution to Managing Mineral Wealth," Perspectives on Politics, Vol. 4, No. 1 (2006), pp. 35-53.

41. Skalamera, "Russia's Lasting Influence in Central Asia."

42. Stronski, "Turkmenistan at Twenty-Five," and Olcott, "China's Unmatched Influence in Central Asia."

43. Stronski and Ng, "Cooperation and Competition: Russia and China in Central Asia," p. 15. See also, Adil Kaukenov, "Shanhayskaya Organizaciya Sotrudnichestva - Burnaya Deyatelnost ili ee Imitaciya (The Shanghai Cooperation Organization - Flurry of Activity or Its Imitation)," $A R K Z$, (July 18, 2013), retrieved from http://arkz.info/news/shanhayskaya-organizaciya-sotrudnichestva-burnaya-deyatelnost-ili-ee-imitaciy.
44. Farkhod Aminjonov, "Central Asian Gas Exports Dependency: Swapping Russian Patronage for Chinese," RUSI Journal, Vol. 163, No. 2 (May 31, 2018).

45. David Trilling, "Water Wars in Central Asia," Foreign Affairs, (August 24, 2016), retrieved from https://www.foreignaffairs.com/gallerys/201608-24/water-wars-central-asia.

46. There is still compliance with existing agreements, but a seasonal variation of water discharge is sometimes compromised.

47. "Russia's Interests in Central Asia."

48. The author's interview with a local expert, Almaty, Kazakhstan, May 2018.

49. "Energy in Central Asia (2) Power Failure," The Economist, (July 26, 2014), retrieved from https:// www.economist.com/asia/2014/07/26/powerfailure.

50. Kyrgyzstan's former President Atambaev denounced the agreement with Russia on building Kambarata-1 HPP.

51. Prior to the deal and subject to the increasing risks of high debt, Kyrgyzstan and Tajikistan (traditionally Moscow's client states) had been turning to China for finances. See, John Hurley, Scott Morris, and Gailyn Portelance, "Examining the Debt Implications of the Belt and Road Initiative from a Policy Perspective," Center for Global Development, (March 2018), retrieved from https://www.cgdev.org/sites/default/files/ examining-debt-implications-belt-and-road-initiative-policy-perspective.pdf.

52. "Kazakhstan-Kyrgyzstan Row: A Spat between Friends or a Parting of Ways?" RFE/RL, (October 25, 2017), retrieved from https://www.rferl.org/a/kyrgyz-kazakh-row-spat-between-friends-partingways/28815387.html.

53. Skalamera, "Revisiting the Nabucco Debacle."

54. In 2015, Kazakhstan, Turkmenistan, Tajikistan, Uzbekistan, and Kyrgyzstan created for the first time a joint platform in partnership with the United States to come together and work on issues of mutual concern, the $\mathrm{C} 5+1$. See, Walker and Kearney, "What Central Asia Means to the United States."

55. Trilling, "Water Wars in Central Asia."

56. See, for instance, "China, Russia Cementing Rising Eastern Bloc as Trump Rattles G-7," Bloomberg, (June 10, 2018), retrieved from https://www.bloomberg.com/news/articles/ 2018-06-10/china-russia-solidify-growing-eastern-bloc-as-trump-rattles-g-7. 

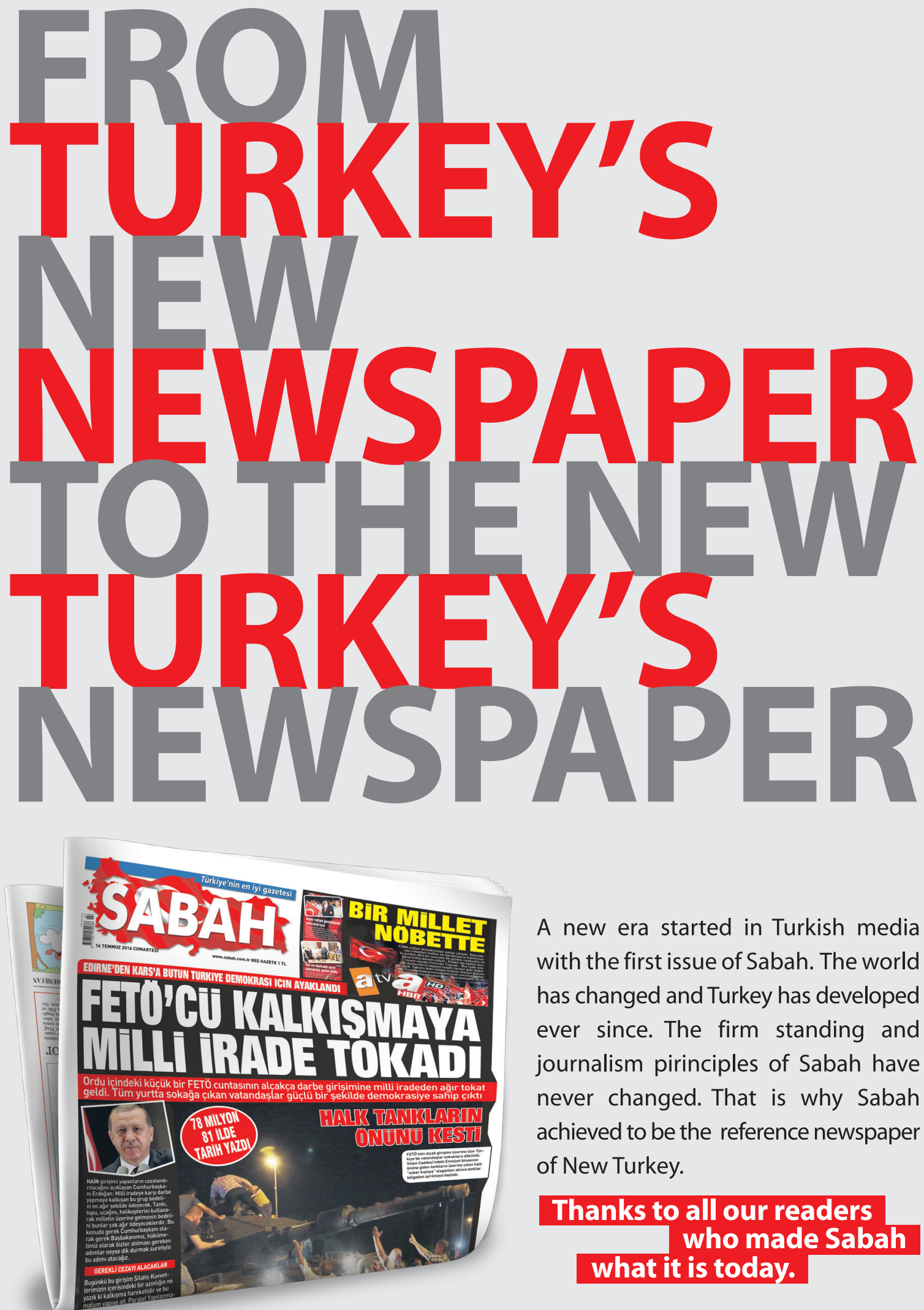

A new era started in Turkish media with the first issue of Sabah. The world has changed and Turkey has developed ever since. The firm standing and journalism pirinciples of Sabah have never changed. That is why Sabah achieved to be the reference newspaper of New Turkey.

\section{Thanks to all our readers who made Sabah} what it is today. 